\title{
Políticas de cultura e comunicação na urbanidade
}

LUIZ ROBERTO ALVES

$\mathrm{N}$ ESTE TRABALHo, deseja-se chegar a valores e métodos das políticas culturais pela crítica da cultura política que tem gerenciado as difíceis operações da sociedade brasileira, com especial atenção às práticas políticoculturais que organizam os municípios. Optou-se pela crítica a alguns mitos políticos e suas conseqüências, que fundam e orientam a sociedade brasileira, do modo de ser colonizado ao modo mediático de fazer política. Aí revela-se o papel das instituições políticas denominadas progressistas e mesmo de esquerda, tanto capazes de acionar novos mecanismos de real progresso cultural quanto de participarem das novas armadilhas da modernidade. Na crítica aos próprios projetos ditos progressistas está a valorização do seu papel possível e a negação das violências culturais dominantes no Brasil. Estas inviabilizaram e inviabilizam novas e mais auspiciosas políticas, sem as quais todos os projetos de modernidade/modernização terminam por se alimentar do encantamento ilusório e que, como das outras vezes (as modernizações de 1822, 1889, 1930, 1955), são seguidas da frustração coletiva, da descrença e do milenarismo tão bem explorados em nossa história, capazes até mesmo de derivar do drama coletivo para a farsa das demagogias e dos populismos, também comuns ao nosso fazer político.

Tratar de política cultural, hoje, implica entrar no cerne dos nossos projetos políticos e de suas formas de disseminação. Porém, tratar das nossas frustrações coletivas exige, também, ver proposições difusamente organizadas no seio das organizações civis que emergiram do próprio interior das modernizações, que se fizeram presentes mesmo quando não desejadas. Vista adequadamente essa tensão, teremos diretrizes para nossas futuras políticas de cultura e comunicação.

\section{Lugares e motivos do cultural}

A questão cultural vista em face dos projetos e práticas políticas de um país liberal e patrimonialista não se revela pelas regras (ou pelos planos nacionais de cultura), mas por suas variações. Ora, o cinema, a literatura e o melhor dos movimentos sindicais do país não se definem nos contornos dos planos oficiais, mas na descoberta de mediações culturais transformadas em ações, linguagens e imagens comprometidas com o país fundamentalmente real, não o do programa $A V o z d o$ Brasil, dos diários oficiais ou dos planos governamentais. Quando se propõe o desenvolvimentismo nos anos 50, com a entrada ampla do capital multinacional e de seus sistemas industriais, produtores das novas cidades, seu favelamento e cortiçamento, publicam-se livros-chave para pensar a nossa modernidade: Morte e vida Severina, de João Cabral de Melo Neto e Grande sertão: veredas, de João 
Guimarães Rosa, nos quais as grandes questões do país: agrária, agrícola, religiosa e suas crises de valores vêm à tona, para lembrar os verdadeiros desafios do país diante de si mesmo e de seu povo. Na seqüência, o Cinema Novo, com Glauber Rocha e, depois, o Tropicalismo.

Do mesmo modo, quando as políticas públicas dos governos da segunda fase da ditadura militar, nos anos 70, evidenciam como seus princípios o patrimonialismo, a concentração de poder, o mecenato e o protecionismo do Estado, movimentos sindicais explodem nas principais cidades do país (e depois no campo, originando o atual e fortíssimo Movimento dos Sem-Terra) problematizando as relações entre capital e trabalho e abrindo caminho para a nova onda de modernização liberal. Efetivamente, o fazer cultural no país colonizado só se faz símbolo, valor, quando é uma circunstância trabalhada a contrapelo, um raio nas trevas, um trilho de vida no círculo da morte. E quando esse quadro é trabalhado no espaço das cidades, dos municípios, pode ser sentido mais agudamente, ou pode ser plenamente dissimulado na proximidade das relações. Ortiz (1994:220), em seu livro Mundialização e cultura, conclui afirmando: "Nossa contemporaneidade faz do próximo o distante, separando-nos daquilo que nos cerca ao nos avizinhar dos lugares remotos". O desafio maior do Brasil não reside somente em conseguir criar a mínima dignidade social nas cidades já quase plenamente comprometidas com a nova fase de globalização da produção e circulação de bens e serviços ( $75 \%$ da nossa população já reside nas cidades); teríamos, realmente, de inverter no laboratório social das cidades o modo perverso do patrimonialismo agrário e de sua contraparte ideológica baseada na teoria dos dois brasis: um arcaico-agrário e outro moderno, das cidades. De fato, a cidade pode ser um grande sertão (já intuído na metáfora de Guimarães: "ser-tão"), onde as relações não alcançam o seu ser, realizando-se com aparências de modernidade, cuja ideologia travestiu-se de direitos na atualização de conhecimento, no lazer crescente, na menor fadiga no trabalho, na maior proteção do Estado, na ampla facilidade na dinâmica da comunicação e direitos crescentes de escolarização e ação cultural, porém que jamais foram fruídos pela maioria. Até porque não se fruem direitos encobertos e ideologizados, no fundo simulações.

$\mathrm{Na}$ sociedade denominada mediática e globalizada mais se confirma a asserção: se não é mais hora de nos agarrarmos ao Estado-muleta ou Estadosuporte, é hora de recriá-lo a partir de nova base de valores, que não se bastam nem se sustentam na privatização da esfera pública. Ainda não vivemos 50 anos (dos nossos 496) de efetiva cidadania político-cultural e as formas de modernização agora observadas (engolidas e aproveitadas por acadêmicos reciclados pela modernidade, bem como por egressos da velha esquerda) podem representar mera simulação para reideologizar o esquema dos dois brasis, agora quadruplicado, sendo dois no campo e dois na cidade, pretensamente arcaicos e modernos. Mais um dos nossos mitos.

Para localizarmos esse espectro político-cultural convém pensar espaços sociais concretos e considerar três fatos: o primeiro, que nossas cidades são, quase todas, frutos da modernidade, como nos observou Santos (1982). Somos modernos 
por contingências do processo de formação do país. A serviço do modo capitalista de produção em sua fase tardia de impulso industrial, depois comercial e de serviços, vimos desenvolver-se nos anos 30,50 e 70 deste século e paralelamente à inserção do país no sistema capitalista de base norte-americana, uma lenta e difícil organização de setores da sociedade civil na busca de fazer com que as nossas cidades superassem a condição de acampamentos, cidades-dormitório, espaço auxiliar do exclusivo crescimento do capital ou lugar de passagem das mercadorias para que ali crescesse a raiz da associatividade social e política, produtora de formas educativo-culturais capazes de aumentar a coesão social e concretizar valores simbólicos indispensáveis para a gestão da vida popular, tentativa de reverter a sina do sertão/ser-tão. Como exemplo, as cidades-chave da região paulista denominada ABC, hoje com dois milhões e meio de habitantes e componentes da metrópole paulista de 17 milhões, cuja grandeza perde somente para a grande México e empata com Tóquio.

A sub-região sudeste da Grande São Paulo, mais conhecida como ABC paulista, ocupa área de $742 \mathrm{~km}^{2}$ e distribui seus dois milhões e meio de habitantes por sete cidades, estabelecendo a ocupação de quase quatro mil pessoas por $\mathrm{km}^{2}$.

Colocada na rota de passagem entre o litoral e o planalto paulista, a região do $\mathrm{ABC}$ já fôra um núcleo colonial no século XVI, desativando-se em razão do privilégio de São Paulo de Piratininga e retornando à condição de povoação, depois vilas e pequenas cidades a partir do século XVIII.

Efetivamente, a região conhece três supersignos em seu desenvolvimento: a condição de passagem de mercadorias e produtos naturais nos séculos XVIII e parte do XIX; a lenta construção da identidade industrial e da autonomia política desde o final do século XIX até os anos 50 deste século; a agudização das tensões entre capital e trabalho na modernidade que ainda vigora, mas já sendo substituída pela civilização de serviços que robotiza o sistema industrial e desemprega $15 \%$ da força de trabalho adulta.

As diretrizes das formas de exploração colonial, pré-capitalistas, cedem lugar aos resultados das revoluções industriais européias que, embora controladas pelas elites locais patrimonialistas, conhecem a substituição da mão-de-obra escrava pelos imigrantes (principalmente italianos), impulsionam a construção da estrada de ferro pelos ingleses, já em operação no ano de 1867, produzem a expansão do sistema industrial a partir de São Paulo com a criação dos subúrbios e partem para a organização classista da sociedade nas operações de educação, cultura, formação profissional, habitação.

Enquanto nos séculos XVIII e XIX essa região de passagem se definia pela pobreza e carência generalizada, o movimento do capitalismo internacionalizado a partir das expansões pós-Segunda Guerra estabelece na região a competência para produzir e acumular capital que, embora renda o suficiente para criar uma ampla estrutura de serviços públicos e uma razoável classe média, concomitantemente produz um processo migratório capaz de inchar as sete cidades e fazer chegar a $20 \%$ a população de cortiços e favelas. 
O grande problema é saber que tipo de associatividade foi possível nesse espaço social organizado para ser linha auxiliar do sistema metropolitano de exploração capitalista. O professor José de Souza Martins (1992) trabalhou a questão na sua memória histórica e livros recentes dão conta das formas de luta possíveis para mudar essa cultura política, a exemplo dos publicados por Bógus (1992) e Kowarick (1988).

Ora, nessas periferias, viu-se o modo oligárquico, familiar e personalista como se deram as sucessões político-eleitorais; o clientelismo e o messianismo dos poderosos foi também regra nas relações de poder. No entanto, a criação desses acampamentos urbanos engendrou a associatividade, a coesão cultural mínima a partir de necessidades vividas que produziram desejos simbolizadores. O que se viu desde o início do século foram greves famosas, grande apoio local na conquista de direitos trabalhistas, movimentos pacifistas de imigrantes e migrantes pela organização comunitária, desenvolvimento de discursos sobre direitos humanos, melhoria da infra-estrutura urbana etc. Pode-se dizer, invertendo o discurso oficial sobre o papel organizador das elites, que as formas necessárias e possíveis de organização social evitaram, sempre, a anomia e a inércia, ou a explosão circunstancial comandada pela oligarquia. No seu esforço de produzir a vida na adversidade, imigrantes-nativos-migrantes produziram uma educatividade na sociedade civil capaz de introduzir alterações importantes no horizonte da cultura regional, abrindo em alguns casos o processo para o próprio país, como ocorreu nos anos 70 .

As tensões que o laboratório capitalista e burguês criou nessa extensão metropolitana produziram segmentos sociais tendentes a escapar ao conformismo perante os estamentos sociais, à mera representatividade política e à condição de objeto histórico, revertendo essas tensões à fronteira em que se questiona o mesmo Capitalismo e a condição burguesa de vida. Os trabalhadores decidiram fazer-se cidadãos dentro do projeto de ser mão-de-obra auxiliar da mais valia; hoje sofrem o novo desafio de não serem somente consumidores de segunda classe e, para tanto, têm como referência o jogo monetarista do capital, a simulação da livreconcorrência e o desemprego crescente. A velha associatividade está posta em xeque, capital e trabalho já não se opõem como nos anos 70, mas as condições gerais de vida não melhoraram para a maioria, o que significa que formas novas de fazer coletivo começam a ser testadas em vista da cidadania obstaculizada.

A proposta que vem dos últimos 20 anos buscava responder à observação dramática de Mumford $(1961,277)$, que dizia a propósito da metropolização: “... as massas passam a viver por procuração (...) como observadores passivos". No entanto, ele mesmo abria o que nestes subúrbios foi intuído e descoberto: "É na cidade considerada como teatro que as atividades propositivas do homem são formuladas e elaboradas, mediante o conflito e a cooperação de personalidades, acontecimentos e grupos, para resultar nas culminâncias mais significativas" (Mumford, 1961:494).

Lembrando Sader (1988:194), para quem os projetos e práticas dessas populações apresenta um modo humanista de viver, a identidade plural dessas cidades periféricas e suas populações migrantes-imigrantes se assentam sobre os seguintes 
pilares: a relativa vitória sobre a desintegração física e simbólica, com a conquista de direitos em meio à tensão crítica; a intercomunicação de segmentos a produzir a condição de pessoa dentro da associatividade de trabalhadores; o aproveitamento dos signos da opulência econômica e política - em parte uma miragem - para a distribuição menos desigual de direitos sociais aos segmentos da sociedade organizada; a busca e, em parte, a conquista da autonomização dos saberes e seu uso político nas organizações populares, a despeito das contínuas operações contrárias à autonomia organizada; enfim, os movimentos sociais dos subúrbios se negaram a reproduzir um poder econômico e social egoísta e produziram, como proposta nova, intenso processo de comunicação social, cujos resultados ainda têm histórias a contar. Identidade significou, ali, a diminuição das distâncias entre o saber e o fazer, seguida das suas conseqüências sobre o comando e a obediência, enfim reorientados para a vida cotidiana. Dialetização intensa das estruturas sócio-culturais, com vitórias precárias na ordem econômica que liga capital a trabalho. Indivíduos e cidadãos buscaram revelar-se cidadãos, cidadãs.

Acrescente-se a isso que a nossa história cultural é feita de carências e abortos. Até 1970 não conhecera qualquer política governamental de cultura e quando a vimos naquela década, era fruto da ditadura travestida de liberalismo, isto é, centralizava o mecenato cultural no governo, estimulava remissão de impostos de empresas para o investimento cultural seletivo, folclorizava as culturas populares e idolatrava o patrimonialismo, pelo qual a memória nacional estava instalada em museus, edifícios e projetos megalomaníacos de preservação da cultura. Para ampliar tal reflexão, consulte Micelli (1984).

Desde o início do século, nenhuma das nossas constituições republicanas abriu espaço para pensar políticas de cultura ou educação, muito menos de comunicação. Os capítulos que tratavam de família, educação e cultura relatavam funções, ordens e procedimentos, repetindo introduções à maneira de constituições estrangeiras deslocadas da seqüência meramente burocrática. Já o tema da comunicação surge nas constituições e emendas do tempo da ditadura militar para apregoar a liberdade de posse e enunciação de discurso, criando a cumplicidade entre os poderes público e privado. Na constituição de 1988, um intenso esforço de intelectuais e trabalhadores das comunicações abre posto para alguma democratização de concessões e gerência dos meios de comunicação, fraudada pela ausência de regulamentações, avaliação e punições aos que buscam continuamente feudalizar o sistema brasileiro de mídia. Aqui, poucas famílias e reduzidos grupos detêm $90 \%$ das redes televisivas, incluindo as novas tecnologias de emissão e repetição, como se ainda estivéssemos no mundo agrário e seu sistema de latifúndio do café, cacau, soja e gado.

Enquanto os trabalhadores empobrecidos dos anos 70 reivindicavam a mínima dignidade de cidadãos/cidadãs nas ruas, a política cultural privilegiava $\mathrm{o}$ patrimônio e, por meio do mecenato, escondia a violência da ditadura militar. Hoje, a democratização enseja ainda maior violência, por obra da degeneração das formas de vida pela agressividade da livre-concorrência e pelo cinismo governamental. Os recentes massacres dos sem-terra revelam todo o quadro. O processo 
político-cultural apresenta homologias, a saber: assim como nossas mais dignas criações populares são cooptadas e travestidas, como o candomblé, o samba e os movimentos musicais, os esforços dos trabalhadores se travestem no universo do consumo e no serviço pouco remunerado. Nos anos 70, enquanto os trabalhadores buscam a cidadania sempre adiada na história do Brasil, gesta-se a criação de uma sociedade culturalmente, e acima de tudo, consumidora, na qual aliam-se as ações governamentais, o mecenato privado-público e os processos mediáticos como ponta-de-lança da indústria cultural. Seus resultados estão, hoje, na crista da onda, exigindo dos trabalhadores empobrecidos o teste de novas formas de ação política. Nunca cultura e política foram tão visíveis nos seus confrontos!

No entanto, nesta terra de tensão contínua, conhecemos resistências, contínua criação popular e certas proposições. Educadas pelo exíguo, pelos restos das culturas burguesa e patrimonialista, pela capacidade de fazer do impossível um espaço de possibilidade, as culturas populares nos abrem espaços para a análise e para o compromisso político.

\section{Prosopopéias populares}

Eu, como tantos, que tenho tido contínua atenção no ouvir, anotar e considerar relatos da experiência vivida e conhecida das cidades, tenho registrado ali a criação e a disseminação da cultura na constituição do possível impossibilitado, da ousadia fustigada, do prazer lastimado, isto é, a criação do símbolo cultural se faz no intervalo, na ponte estreita que vai da sua negação ao direito de sorrir, de criar memória, de refazer uma ponta de esperança.

Para exemplificar pouco, tanto as histórias de vida, os movimentos de moradores sob repressão, a criação da cerâmica pobre do Jequitinhonha, Minas Gerais, quanto as narrativas dos cantadores, as brincadeiras infantis nos espaços de cortiços e favelas, os recados que escapam à mistificação do programa televisivo Aqui/Agora, algumas frases soltas dos jogadores do Baú da Felicidade do proprietário e animador de TV Silvio Santos (Senior Abravanel), ou os intervalos narrativos e pictóricos dos escritores Euclides da Cunha e Graciliano Ramos, do pintor Portinari ou do primitivista anônimo - nesse painel diverso e problemático das culturas brasileiras são signos e símbolos do alcance de um valor dentro de uma memória maior do desvalor, o possível no projeto maior da impossibilidade. Foi assim que as mulheres e os homens considerados degenerados em Os sertões, de Euclides, (degenerados porque escuros, mestiços, de acordo com as concepções científicas racistas da época) não somente lutaram bravamente, como operaram alta criatividade no seu esforço de sobrevivência, mesmo sem comida e outros meios de existência. Foi assim quando ouvi da participante do projeto de terceira idade, (membro do grupo de teatro), em face da sugestão médica para que tivesse cuidado com o cansaço, que poderia afetar o coração já não muito bom: "Doutor, deixo de cuidar dos netos e ajudar minhas filhas, mas do teatro não largo não!"

A simbolização cultural se ordena no contexto da adversidade. Mas também sinaliza esse mesmo valor quando se cruzam as ruas de algumas cidades brasileiras administradas com carinho e coragem. Em São Paulo cito Jaguariúna e 
Diadema. Se você alternar suas visitas, terá a impressão de que uma nova cidade se faz a cada alguns meses; se passar por ali mais amiúde, sentirá um refazer-se em acumulação de sinais anticaóticos, reordenação do desordenado, ampliação de espaços uma vez encalacrados, fluidez do entupido. Ora, a aglomeração espalhada entre a periferia paulistana e a rodovia dos Imigrantes, associada aos espaços que perderam a hegemonia do café, tinha tudo para não dar certo, acumulando a anomia do poder à impotência dos despossuídos. Mas os últimos governos municipais instauram ali signos consistentes de resistência frente à lógica da degeneração programada, cujos sinais foram dados no processo de urbanização e industrialização do início do século e que não encontraram sensibilidades para armar as resistências, tanto em São Paulo quanto no Rio de Janeiro e outras hoje metrópoles.

Destaco, para não citar outras cidades, as gestões de cultura e comunicação concretizadas entre 1989 e 1992 pelas cidades de Curitiba, Santo André, Belo Horizonte, São Bernardo do Campo e capital paulista, documentadas pelo Instituto Pólis (Faria \& Souza, 1993). Outro valor, que também observei, foi a criançada fazendo educação física - e educação de corpo inteiro - entre as dunas de Icapuí, Ceará, ou combinando cenas teatrais na sala de visitas do prefeito. Vi, também, em uma pequena cidade do interior de São Paulo crianças fabricando violinos e depois usando-os na musicalidade que faz da cultura exatamente o que ela precisa ser, a invenção do tempo e a desmistificação da sociedade de classes.

Temos visto e ouvido cenas e sinais dessa cultura reagente à lógica liberalpatrimonialista, tanto nos encontros e publicações do Instituto Polis, de São Paulo (certamente há muitos centros de documentação e ação no país), no material de pesquisa sobre as lutas nas cidades, nos modos progressistas de governar dezenas de cidades, grandes e pequenas, e no cotidiano observado. Não se pode, no entanto, garantir muita resistência a esses sinais, por causa dos defeitos da educação colonizadora e patrimonialista já denunciados e minados pela pedagogia de Paulo Freire (1978, 1985).

Precisamos reconhecer que vivemos em um país essencialmente barroco, que faz incidir o projeto colonizador sobre os enganos das modernidades e depois faz do povo aquele que busca no interior do sistema cruel as metáforas do céu e do inferno, do claro e do escuro, metamorfoses políticas travestidas em valores religiosos e messiânicos. Aí, a primeira lógica da vida social é a reversibilidade, na qual o ouro (da natureza e da civilização culturalmente rica e diversa) se confunde com o ferro (do colonialismo de dentro e de fora) e a remela se faz pura lágrima; a despeito disso, no entanto, lembrando o auto de natal pernambucano Morte e vida Severina, tais práticas são sinais da vida assim franzina, renitente e persistente a marcar presença pretensamente acumulável.

A cultura, em países de experiência como a brasileira, é um intervalo do que eu chamaria de consciência-iceberg da totalidade possível o qual, via de regra, se rouba, esconde ou mistifica, mas se entrevê e se sente num átimo redentor. Ora, visto que nossas cidades são, todas, frutos da modernidade fundadora, e a própria modernidade brasileira representa a transposição do domínio colonizador e patrimonialista, a reflexão sobre o município não prescinde da análise do conjunto 
social. Se aqueles momentos redentores da cultura, ou de captação da totalidade, não crescem ou não se confrontam com as hegemonias tradicionais em pé de igualdade, isso não se dá por defeitos atávicos, falta de memória do povo ou somente por via da cooptação ideológica, mas porque os sinais de redenção passam a se disciplinar como burocracia em vez de se educarem para serem símbolos, isto é, valores arbitrados pelo reconhecimento coletivo. Por isso, é ardiloso, senão ingênuo, que se metam cidadãos/cidadãs da esquerda ou ex-esquerda política no Ministério da Cultura, até que por ali passe uma revolução cultural que não reverta a vontade, os sinais das ruas e as concepções diversas de cultura ao claustro da cultura tecida como patrimônio de exclusão, ou simulação.

Convém dizer que esses momentos inquietaram e instigaram os observadores da vida brasileira: os mais argutos e honestos produziram memórias instigantes e produtivas, como se vê na literatura, no folheto popular, no teatro, na cantoria e em algumas análises críticas; os menos argutos ou mais cooptados folclorizaram esses momentos redentores como coisa do passado, assunto da memória burocrática ou exótica, ações curiosas que não movem mais moinho algum. Por isso nós pudemos, a partir de leituras que ajudaram a explicar, mesmo canhestramente situações da Europa e dos Estados Unidos, criar separações de qualidade e valor entre culturas denominadas eruditas e populares e fazer políticas especiais para ambas: de um lado, o cultivado, o elevado, o complexo; de outro, o fácil/facilitado, a não-ciência (por isso folclore), o espontâneo. Fizemos mistificação, que penetrou amplamente também na consciência das esquerdas e dos esquerdistas, do sentido de progresso e dos progressistas. O que sempre foi palavra de ordem para os donos do poder colonizador, imperial e republicano migrou para a consciência progressista como requinte, adorno, meta do crescimento das massas, sinal claro da cultura não-inclusiva da consciência diversa. Um dos lugares privilegiados da mistificação, além dos ministérios e secretarias, é a escola, qualquer tipo de escola, lugar de cristalização da cultura. Outro é o partido político, no qual a cultura é mestre-sala a abrir espaço para o carro alegórico do fulano de tal.

É, pois, necessário reconhecer que os componentes aqui refletidos do momento redentor da cultura, da não-educação para o simbólico e da escolaridade da cultura vivem e vicejam no universo das políticas partidárias e, por decorrência, das políticas administrativas, da união federal ao município. E reconhecer, antes de tudo, que toda política cultural precisará ter como objetivo e referência a desmistificação da cultura política colonizada/colonizadora e a criação de outra, aberta aos direitos e deveres da cidadania.

\section{Os discursos progressistas e seus avessos}

Mas não seriam bons e eficientes os discursos progressistas, ou da esquerda política, sobre a cultura? São certamente bons como enunciado, mas se traem no processo de enunciação. Explico-me. Via de regra esses discursos fazem do cultural ou uma projeção superestrutural, e aí se encontram no universo idealista, ou o encaixotam na infra-estrutura, materializando-o no limite. Pena que não tenhamos visto, sentido e praticado que o cultural é um valor de mediação, como também o é a língua. Cultura como mediação é uma base de motivos, valores e estí- 
mulos à ação criativa e diferenciadora dos grupos que buscam organizar-se como comunidade.

A mediação cultural não foi vista claramente nos manifestos modernistas dos anos 20, nos programas partidários progressistas, comunistas, socialistas e petistas. Neles há um forte apelo à cultura do povo, o que é positivo, porque a menção já se constitui oposição à cultura das elites, dos donos do poder. No entanto, as substâncias cultura do povo, produção cultural e cidadania cultural vão cedendo espaço, nesses textos e discursos, aos ideais de cultura, entre eles a própria defesa da cultura, ou a fazer da cultura pretexto para a mudança das condições de existência. Ora, cultura defendida é cultura circunscrita e ordenada, caminho para a sua folclorização, bem como cultura como ariete da luta sóciopolítica é sinal de sua estereotipia e até de sua transformação em objeto, produto. Assim se deu com as esquerdas e hoje se dá com o liberalismo a cavalo da indústria cultural. De um lado, o uso ao modo estritamente positivista; de outro, mas complementar, a sua folclorização. Aliás, quem melhor generaliza o uso das culturas populares e as defende são as elites, em suas produções bonitas e de grande qualidade técnica, quer de bancos, quer de grandes empresas industriais. Defendemnas a seu modo e segundo o seu entendimento, como patrimônio folclorizado do acervo nacional ou regional.

Já as populações que buscam fazer de seus valores instrumentos do cotidiano, em vez da defesa e estereotipia da cultura, de fato o fazem e refazem como marca de atualização e diferenciação, como memória em movimento, como forma de vida e mediação indispensável entre si e a sociedade, natureza fazendo-se cultura. Assim, o empresariado e até mesmo o governo publicam belos relatos da cultura enquanto metem cenários da luta cultural sob as águas dos açudes e represas, ou abaixo das fundações dos hotéis de luxo, como Monte Santo, na Bahia, e os sambaquis do litoral. De seu lado, a velha senhora transformada em artista dispôs-se a abandonar filhos e netos pelo teatro, referência de vida, como as invenções infantis sinalizam que as águas passadas movem moinhos e as favelas e cortiços são espaços de intensa experiência cultural. Cultura defendida é cultura manipulável, produto de um grupo social projetando-se no todo social. Cultura levada a sério como mediadora é lugar de invenção e criação da vida. As periferias dos trabalhadores paulistas dos anos 70 e 80 se reinventaram precisamente pela mediação cultural, na qual tempos, memórias, gestos atualizados, transposições da educatividade jogam renovados papéis nas diversas conquistas cotidianas da cidadania.

É pena quando o discurso sobre a cultura se faz moeda de troca barata.

Hoje, quando um ministro ou um presidente de instituição influente ou um administrador público fala em cultura, devemos ficar atentos: pode surgir no seu discurso a cultura inflacionária, cultura de inadimplência, cultura do jeitinho etc. Os acadêmicos falam de cultura do narcisismo, cultura científica e cultura do consumismo. Há muitas outras. As citações, enquanto indicam o leque aberto de espaços da ação cultural, fazem apagar referências, afundam memórias no relativismo do vale-tudo e participam da intuição do fim de um ciclo (que não faz mudar para 
melhor a real condição da cidadania, mas se basta na retórica da discursividade). Os mesmos que defendem o fato folclórico, o artesanato ou o museu generalizam a deformidade econômico-social como cultura (cultura inflacionária), fazendo passar por símbolo de um mal difuso e sem rosto o que de fato é prática política resultante das estruturas político-sociais longamente fomentadas, cuja solução se dá por práticas e leis contrárias àquela prática deformadora. Ora, o jeitinho, a inflação, a recessão e o narcisismo não são fatores de coesão; ao contrário, são o resultado da deformidade política. Não são símbolos e sim instrumentos para a produção do jogo ideológico maior, sustentador do poder. Os discursos sobre cultura disso ou daquilo são fórmulas para cristalizar concepções e abrir frente para os diversos projetos ideológicos sempre em novos trabalhos de parto. Antes de citá-los para fazer um dicionário insosso de culturas caberia a nós analisá-los em seus fundamentos de sentido e ação sócio-política.

Por isso, ao produzir propostas de política cultural, nos municípios que tentam fazê-lo, o administrador corre vários riscos. O mais grave é a redução cultural da cidade à mitologia política local, que determina a prática dos agentes culturais e até dos produtores, notadamente nos espaços sociais em que ainda é tênue a organização da sociedade civil e de seus movimentos. A mitologia política dilui as bases espiritual e material de que se forma a cultura e suas práticas.

\section{Opções não-mistificadoras}

Devemos superar a gangorra em que se mete a cultura; somente infra ou superestrutura social. Ora, quando a cultura é preferencialmente tratada na superestrutura, o cotidiano, a gestualidade no trabalho e os valores lentamente acumulados na relação entre o real material e a sua transformação simbólica, tudo isso se torna opaco, coisa de segundo plano, detalhe. Mas vista como infra-estrutura, perecem a memória, os sentimentos de religiosidade, a própria dialética da tradição posta na mira do moderno. A questão central das culturas populares (porque elas preocupam mais os programas partidários) é que se organizam como história dentro do fazer político concreto, sem negar as formas industrializadas e globalizadas da cultura, assumindo a vida material difícil, pobre, mas aberta; por isso suas identidades são complexas (como são complexos os códigos culturais que nos orientam no universo das vilas e favelas...)

Colocadas na mira do poder hegemônico, proprietário dos vários capitais que movem a sociedade, essas culturas tecem seus momentos de superação dos bloqueios e ataques sofridos, produzem seus valores simbólicos dentro do possível que a matéria da vida lhes conformou e se organizam como linguagem paralela (embora comunicante) àquela outra que a escola, a universidade e mais modernamente os meios de comunicação de massa produzem. No mínimo, são resistência. Quando a superam, são indicadores das contradições da sociedade. Se avançam, são o princípio da revolução social. Ora, o programa Sílvio Santos (e seus similares), o sarau acadêmico e a publicação folclórica dos bancos e conglomerados financeiros dos meios de produção não esgotam nem reproduzem os diversos sentidos da torcida de futebol, da invenção musical, da novena ou da folia 
de reis e as diversas formas de ação pela cidadania, das greves à reorganização do espaço-cenário do outro massacre em Vigário Geral, Rio de Janeiro.

Se a cultura não for um valor central de mediação entre a infra e a superestrutura social, não servirá ao projeto político transformador. E não é isso que os projetos de organização de bairro, alguns movimentos de defesa dos meninos e meninas marginalizados, os projetos de terceira idade e já antes as ações de politização da vida sindical tentaram e tentam mostrar? Neles, a vida comunitária ou o espaço humano da fábrica, do comércio e dos serviços é mediado por valores revistos, transformados e atualizados pela coesão social mínima e necessária. A seguir, com base nesse baú cultural e em face das mudanças da modernidade, esses setores da população têm garantido, de um lado a expansão do valor do trabalho em face do capital e de outro a demonstração de que é necessário reagir sempre para que não se tornem bagaços de cana chupada pelo modo capitalista de produção. Nessas culturas, somente a junção da vida material e da vida espiritual-simbólica garante o seu avanço social e político, entre marchas, contra-marchas e contradições. À luz dessas práticas culturais, como método, não será difícil trabalhar as culturas do narcisismo, da lamentação, da grã-finagem, do desempenho etc. No mínimo, não nos perderemos nesse fim de história, entalados e sufocados pelo máximo de conceitos e mínimo de interpretação.

Nesse contexto, o enunciado de alguns textos partidários sobre a cultura, embora bons como marca de oposição, amiúde mostram o lastro elitista, senão hegemônico dos seus emissores, cuja enunciação carrega a força da cultura escolarizada, ou a doutrina partidária projetada sobre a ação cultural popular, a que se acresce hoje a produção simbólica da mídia, lida e vista também na escola e no partido. Surge aí o conflito, pois o cultural é valor mediador, referência indispensável para a organização e reorganização da vida individual e coletiva. O enunciado escolar e partidário, mais ou menos dogmático, em todo caso será lido e interpretado como um produto, entre outros referenciais (também os produtos da indústria cultural) dispostos ao entendimento ou à confusão no seio da população.

Portanto, o discurso chamado progressista sobre a cultura no Brasil não oferece qualquer garantia ao projeto de avanço cultural. Mais por defeitos de enfoque e concepção do que pelo esforço e desejo na criação da cultura, sabendose que esses os temos bastante. Escola e partido precisariam deixar de ser, com urgência, lugar de assimilação da confusão conceitual e de redução de sentidos: escapar do vale-tudo ou do dogmatismo, da mitologia diluidora da cultura.

\section{Proposições}

Entendo, pois, que uma política cultural, quer produzida pelos partidos, pelas administrações públicas, quer por setores comprometidos de outras instituições da sociedade civil precise assumir um modo de ser compatível com a diversidade e o caráter mediador da cultura, ou seja:

- Estar pronta a acompanhar essa mediação entre a infra e a superestrutura, 
isto é, ver como os grupos e comunidades produzem a memória do que fazem, como organizam o seu orçamento familiar e grupal, de onde arrancam conceitos e costumes para se organizarem no espaço de vida (rural ou urbano), como e para quê realizam a superação da sua condição na vida dos seus filhos e com quais motivos e materiais compõem sua expressão estético-artística. Em outras palavras, o pesquisador, o político e o comunicador deveriam ter olhos e ouvidos grandes e boca pequena diante do painel cultural que se descortina, intriga e desafia no Brasil. Seria como fazer o contrário dos textos de política cultural emanados da oficialidade cultural do país, quer aqueles dos tempos militares de Ney Braga, quer os posteriores. Falta sempre a interlocução ampliada. Bocas grandes e olhos e ouvidos miúdos. Por isso, a cultura vira esquema e não vida vivida e compartida.

- Produzir mais narrações e descrições da cultura para superar o ecletismo e o dogmatismo. Mostrar os laços teórico-práticos que organizam o fazer cultural da cidade e suas periferias, as relações concretas do continuum educação/cultura, arte/cultura, lutas sociais/cultura, cultura/saúde etc. A narratividade da cultura não somente significará uma retomada do velho e bom hábito de vivenciar a cultura e contar a sua história, acumular memória, mas será também um modo de se opor ao discurso dos princípios que projeta dogmas e concepções sem considerar a dialética do real.

- Assumir metodologias de trabalho que levem às últimas conseqüências e posicionamento político. Como exemplo, não será possível anunciar a importância do cultural em dada administração pública e depois negar um mínimo de $2,5 \%$ do orçamento total para a ação cultural. Outra questão será o da restrição conceitual de cultura, resultante da sociedade colonizada e do discurso bacharelista que divulga essa restrição. Chega o momento perigoso em que a ação cultural na cidade se distancia da luta pela água, pela melhoria da educação, pela reorganização do bairro. Aí morre a mediação e se sufoca mesmo a proposta transformadora da cultura, que os partidos, administrações públicas e demais entidades progressistas da sociedade civil anunciaram e anunciam. Desse modo, as melhores reformas da legislação são aquelas em que orçamentos, incentivos e outras políticas econômico-financeiras vigiam e mensuram rigorosamente os projetos e programas capazes de verem a cultura como processo de articulação dos diferentes âmbitos da consecução da cidadania. Precisamos de leis que sejam o oposto das do tipo Sarney, quer na concepção do sentido da cultura, quer no modo de decisão e acompanhamento dos investimentos, quer na sua avaliação contínua. Mas cuidem-se os que propugnam a cultura como negócio numa sociedade na qual a categoria trabalho (com desemprego de 15\%) é valor de sobrevivência e dignidade e negócio pode chegar a ócio, como no poema de José Paulo Paes. Ócio não rima e nem se afina com desemprego e o Ministério da Cultura não deveria ser um balcão de transações. 
- Aprender a fazer educação na ação cultural e culturalizar a educação. Aprender dos erros cometidos nas administrações dos bens públicos, ou seja, atender a todas as demandas populares sem criar o confronto cultural com a realidade e suas prioridades. Aprender a nunca deixar um dia sem realizar atos que acumulem a simbolização cultural. Acreditar que são necessários alguns edifícios e espaços construídos, mas crer mais ainda que é possível inventar espaços como invenção educativa e criação de futuro desburocratizado e aberto. Acreditar profundamente na educação dos que trabalham em projetos e programas interculturais, não adiantando reclamar da incompetência deles sem operar a confiança na educação culturalizada.

- Assumir um fazer cultural total. Levar a sério a cultura que tem um braço tradicional, entre artes e letras, mas ver que as artes e as letras compõem o ser profundo da cultura, que se faz em gestos e olhares voltados para todo o fazer humano. Descobrir e revelar o fazer cultural que também se estetiza na escola, na luta dos sem-teto e sem-terra, no trabalho com meninos e meninas de rua, na nominação das praças e ruas, nos projetos de ecologia e na ginástica coletiva. Se a cidade não desenvolver símbolos culturalmente politizados, a administração das coisas públicas será inócua, mesmo que possuidora de algum poder eleitoral.

- Assumir a disposição de se recriar o espaço público a partir do fenômeno da globalização, que faz próximo o distante e distante o próximo. Em ação cultural, isso significa a recriação da memória popular, o debate intenso para superar preconceitos e valores apriorísticos e a contínua avaliação do trabalho como garantia da sua qualidade.

\section{Breve digressão sobre o vivido}

Não se pode dizer que programas públicos progressistas não tenham produzido boas seqüências de trabalho, melhores projetos e muito esforço. Não debalde, mas sob incômodos.

Podemos dizer, feita a leitura dos relatos e observado o trabalho de secretários de cultura, ex-secretários, presidentes de fundações e funcionários diversos, que um número nada desprezível de municípios, tanto dos espaços metropolitanos quanto do interior dos estados, fez propostas concretas para inverter prioridades, acompanhar com zelo e coragem o desdobramento dos projetos e buscou a reeducação dos modos e instrumentos de ação cultural. Não sem tensões (ao contrário, com necessária tensão), vimos departamentos e secretarias de cultura tentarem costurar um novo hábito para o conjunto das administrações públicas. Como presidente da Associação dos Dirigentes Municipais de Cultura do Estado de São Paulo (1990-1991), vi ações culturais que superaram projetos de governos conservadores. Aquela idéia que vivenciamos de 1989 a 1992 sobrevive e se desenvolve agora no Fórum Intercultural de Secretarias, com base mais ampliada e incluindo secretários e diretores municipais de cultura de vários estados. 
Ao inverter prioridades, as secretarias, departamentos e fundações obstaculizaram a política do balcão de negócios culturais e implementaram intervenções para públicos crescentes e antes esquecidos. Chegando ali num misto de assistência e desafio, o projeto ou a idéia teve no próprio diálogo com as populações a purgação da consciência infeliz da cultura como ideal de vida, produto da erudição ou instrumento da razão politiqueira, avançando depois para parcerias de gestão, autogestão, politização crescente da mediação cultural e ampliação das referências para a prática cultural. Assim, redirecionaram-se ações, equipamentos e hábitos. Mexeu-se com a cultura, mexendo-se com a política e sua história. O Brasil, capitais e cidades do interior têm muita história a contar sobre essa mexida cultural.

Os dirigentes de cultura com quem privei, em contínuo intercâmbio, dedicaram-se em tempo integral ao seu mister. Abandonaram pesquisas, cursos, carreiras. Não aceitaram a mediação burocrática, mas desejaram estar eles próprios presentes no cenário dinâmico das ações. Daí resultou a consciência (às vezes dolorosa) dos avanços e contradições da administração da cultura, bem como as armadilhas do discurso progressista, que se acostumou a ficar no meio do caminho, entre a fé na ação cultural popular e a crença na tutela do governo ou do Estado. Por isso adiaram-se tantas realizações, postergaram-se utopias possíveis, até mesmo evitou-se a invenção. Já dissemos que faltou a radicalização de irmos, como disse Guimarães Rosa, "até o rabo da palavra", o que não significa ser dogmático ou obtuso, mas dedicado a descobrir todos os significados dos discursos e das práticas com que trabalhamos.

Muitas administrações têm sido reconhecidas como competentes para investir nos recursos humanos e materiais. Por isso, nas cidades em que a postura político-ideológica mudou amplamente, já se sente saudade do esforço educativo, do trabalho em grupo, do acompanhamento avaliativo das ações. Até porque a fragmentação quantitativa conhecida como moderna não se politiza, porque nega mediações e não acumula porque se basta na criação de coisas eventuais, mais estéreis ainda do que sempre na sociedade inflacionada de informação.

\section{Alternativas de recriação política}

Não desejo, pois, reconhecendo os nossos valores, voltar a afirmar nossas ausências, deficiências e equívocos, já enumerados. Quando mistificamos o fazer cultural, ou fizemos clientelismo na prática global da administração pública; quando postergamos a boa radicalidade ou ignoramos as armadilhas da modernidade patrimonial, em tudo ficou patente o nosso engano quanto aos modos de simbolização cultural das culturas populares, quanto às nossas concepções de cultura e nossa dificuldade no acumular da experiência.

Invertendo a imagem de Drummond, de tudo o que fizemos ficou o bastante para não admitirmos mais a patinação pantanosa que tem caracterizado o nosso fazer cultural. Nessa fase de urgência perante a transformação profunda das esferas públicas, entre valores que devem ser louvados, vigiados e refutados, continuo a acreditar que se os setores políticos comprometidos com a melhor quali- 
dade de vida para todos (o que significa a revolução), tiverem olhos e ouvidos enormes e boca menor no aprendizado e no reaprendizado do fazer, da circulação e do consumo das culturas, os seus projetos serão a melhor alternativa de recriação política do Brasil, que não alcançaremos fora do repensar e do refazer cultural.

Referências bibliográficas

BÓGUS, Lúcia Maria M. et al. A luta pela cidade em São Paulo. São Paulo, Cortez, 1992.

FARIA, Hamilton \& SOUZA, Valmir de (orgs.). Experiências de gestão cultural democrática. São Paulo, Revista do Instituto Polis, n.12, 1993.

FREIRE, Paulo. Pedagogia do oprimido, $5^{\text {a }}$. ed. Rio de Janeiro, Paz e Terra, 1978.

. La invasión cultural. In: Cultura y resistencia cultural: una lectura política. México, Ediciones Sep-El Caballito, 1985.

KOWARICK, Lúcio (org.). As lutas sociais e a cidade. Rio de Janeiro, Paz e Terra, 1988.

MARTINS, José de Souza. Subúrbio. Vida cotidiana e história no subúrbio da cidade de São Paulo. São Caetano, do fim do Império ao fim da República Velha. São Paulo, Hucitec/Prefeitura de São Caetano do Sul, 1992.

MICELLI, Sérgio (org.). Estado e cultura no Brasil. São Paulo, Difel, 1984.

MUMFORD, Lewis. A cidade na história: suas origens, transformações e perspectivas. São Paulo, Martins Fontes/Editora da Universidade de Brasília, 1982.

A cultura das cidades. Belo Horizonte, Itatiaia, 1961.

ORTIZ, Renato. Mundialização e cultura. São Paulo, Brasiliense, 1994.

SADER, Eder. Quando novos personagens entraram em cena. Experiências e lutas dos trabalhadores da Grande São Paulo, 1970-1980, $2^{\text {a }}$. ed. Rio de Janeiro, Paz e Terra, 1988.

SANTOS, Milton. Ensaios sobre a urbanização latino-americana. São Paulo, Hucitec, 1982.

Luiz Roberto Alves é professor e pesquisador da Universidade de São Paulo, livredocente em Comunicação e Artes, assessor de movimentos sociais, ex-secretário de Educação, Cultura e Esportes de São Bernardo do Campo (1989-1992). 